\title{
Duct Systems in Large Commercial Buildings: Physical Characterization, Air Leakage, and Heat Conduction Gains
}

\author{
William J. Fisk, Woody Delp, Rick Diamond, Darryl Dickerhoff, Ronnen Levinson, Mark \\ Modera, Matty Nematollahi, Duo Wang \\ Indoor Environment Department \\ Lawrence Berkeley National Laboratory \\ Berkeley CA 94720
}

March 30, 1999

\begin{abstract}
Through field studies in large commercial buildings and reviews of building plans, we investigated the effective leakage areas (ELAs), air-leakage rates, and conduction heat gains of duct systems. Different methods for measuring air-leakage rates were also compared. ELAs of supply ducts ranged from 0.4 to $2.0 \mathrm{~cm}^{2}$ per square meter of floor area served, and from 1.0 to $4.8 \mathrm{~cm}^{2}$ per square meter of duct surface area. On a per-unit-floor-area basis, these duct ELAs are comparable to the values measured in residences. The corresponding values of duct leakage class were 60 to 270, much higher than the range of 3 to 12 reported by ASHRAE as attainable for quality duct construction and sealing practices when leakage at connections to duct-mounted equipment is not considered. The measured air-leakage rates as a percentage of the inlet air flow rate varied from $0 \%$ to $30 \%$, with most of the measurements falling between $10 \%$ and $20 \%$. Large inconsistencies among the air-leakage rates determined from different measurement procedures exemplify the need for further development and evaluation of measurement methods. Heat gains between the outlet of the cooling coils and the supply registers caused supply-air temperatures to increase, on average, by $0.6^{\circ} \mathrm{C}$ to $2^{\circ} \mathrm{C}$. The corresponding values of conduction effectiveness were 0.75 to 0.90 ; thus, heat conduction decreased the cooling capacity of the supply air exiting registers by $10 \%$ to $25 \%$. Because these results are based on studies in only a few buildings, generalizations from these findings are premature.
\end{abstract}

\section{INTRODUCTION}

Duct systems are used in most commercial buildings to transport conditioned air between heating and cooling equipment and the occupied space. Ducts also distribute outdoor air to the occupied space and exhaust indoor air to outdoors. 


\section{DISCLAIMER}

This document was prepared as an account of work sponsored by the United States Government. While this document is believed to contain correct information, neither the United States Government nor any agency thereof, nor the Regents of the University of California, nor any of their employees, makes any warranty, express or implied, or assumes any legal responsibility for the accuracy, completeness, or usefulness of any information, apparatus, product, or process disclosed, or represents that its use would not infringe privately owned rights. Reference herein to any specific commercial product, process, or service by its trade name, trademark, manufacturer, or otherwise, does not necessarily constitute or imply its endorsement, recommendation, or favoring by the United States Government or any agency thereof, or the Regents of the University of California. The views and opinions of authors expressed herein do not necessarily state or reflect those of the United States Government or any agency thereof or the Regents of the University of California. 
In large commercial buildings with spaces larger than approximately $1000 \mathrm{~m}^{2}$ served by single air handling systems ${ }^{1}$, the larger ducts with cross section dimensions up to several meters, are usually constructed from sheet metal or from a rigid fiberglass material, sometimes called fiberglass duct board. Smaller ducts, often with a diameter of 15 to $30 \mathrm{~cm}$, connected to airsupply registers may be flexible ducts, containing a helically-wound wire for structural rigidity, a layer of coated non-rigid fiberglass ${ }^{2}$, and an exterior plastic sheet. Duct systems in large commercial buildings may include a large variety of components such as dampers, turning vanes, variable-air-volume control units, cooling or heating coils, supply and return registers, and sensors for temperature, humidity, smoke, carbon dioxide concentration, pressure, and flow rate. Duct systems are usually constructed of many interconnected duct sections, and the junctions between sections (as well as junctions between ducts and other components) are often locations of air leakage.

One source of energy losses in duct systems is the conductive and convective heat transfer between the air inside ducts and the surrounding air (hereinafter called conduction losses). To reduce the rate of conductive losses in sheet metal ducts, and for acoustic control, these ducts may have a layer of external or internal insulation, e.g., a $2.5 \mathrm{~cm}$ (1 in) thickness of fiberglass. Commonly, only a portion of the ductwork is insulated.

Air leakage into or out of ducts is another important source of energy losses. Air-leakage rates in commercial building duct systems are very difficult to measure accurately; however, a synthesis of measurements from a set of light-commercial buildings in California suggests an average leakage rate in supply ducts of approximately $25 \%$ of the flow through the supply fan (Levinson et al. 1997, Delp et al. 1998).

Prior research on the energy losses of ducts in large commercial buildings is very limited. Investigations in residences and small- or light-commercial buildings have determined that large energy losses occur due to both air leakage and conduction. For example, in field studies of light-commercial buildings, Delp et al. (1997) determined that the cooling capacity of air delivered through supply registers decreased by $10 \%$ to $40 \%$ due to conduction losses. The associated temperature increases in the supply airstreams, between the supply plenums and the supply registers, ranged from 0.5 to $6{ }^{\circ} \mathrm{C}$.

Designers and fabricators of heating, ventilation, and air conditioning systems in large commercial buildings have often been unconcerned about energy losses caused by air leakage or heat conduction, because these ducts are typically located inside the conditioned interior of the building (e.g., within the plenum above a suspended ceiling). However, conduction losses and leakage will increase HVAC energy use even when ducts are located in the conditioned space. For example, to overcome the leakage and conduction losses and maintain indoor thermal conditions at set points, the rates of airflow through fans must often be increased, leading to an increase in fan energy. As fan energy use increases, the amount of fan heat that must be removed by the cooling system also increases. The influence of air leakage and conduction losses on

\footnotetext{
${ }^{1}$ Small commercial buildings served by small roof-top air handling systems usually have a very different duct system. Air from the air handler is supplied to a sheet-metal plenum and flexible ducts run between the plenum and the registers. Some larger buildings with many small air handlers also have this type of duct system.

${ }^{2}$ The interior surface of flexible ducts is lined with a material that is either impermeable or permeable to air.
} 
HVAC energy use will depend on many factors, including the method of airflow control in the HVAC system, the locations of air leaks, and the locations of ducts. As an example of the energy impacts, Franconi et al. (1998) have predicted a 65\% increase in fan energy and a $10 \%$ increase in cooling coil loads when $20 \%$ of the supply air leaks from the supply ducts of a variable air volume (VAV) system with the fan speed controlled by a variable speed drive.

\section{RESEARCH OBJECTIVES}

This paper describes research with two primary objectives: (1) to characterize energy losses in the duct systems within large commercial buildings, along with the pertinent physical features of the ducts; and (2) to develop and evaluate methods of measuring duct system energy losses. Our broader program of research on large commercial ducts includes modeling to quantify the influence of these losses on HVAC system energy use (Franconi et al. 1998) and an investigation of the feasibility of sealing ducts in large commercial buildings by injecting sticky aerosols into the ducts (Modera et al. 1998).

\section{RESEARCH METHODS}

\section{Duct System Physical Characterization}

Dimensional characteristics of duct systems in large commercial buildings, such as duct diameters, lengths, and surface areas, were compiled based on a review of plans and inspections of installed duct systems. Because of the excessive effort required to characterize entire duct systems in large buildings, representative sections of ductwork were characterized. The sample of buildings and building plans was one of convenience. We intentionally characterized ducts from a variety of HVAC system types, e.g., constant-volume, variable air volume, single-duct, and dual-duct systems.

\section{Measuring Temperature Gains in Duct Systems}

Conduction heat gains in sections of supply-air ductwork were characterized by monitoring and recording air temperatures at selected supply registers and also just downstream of cooling coils. Small battery-powered temperature sensors with external thermistor sensors and integrated data loggers (On-set Corporation, Stowaway XT1) were used to measure temperatures. The resolution of the these sensors is $0.2{ }^{\circ} \mathrm{C}$ and the rated accuracy is $\pm 0.3{ }^{\circ} \mathrm{C}$. A comparison of sensors yielded a maximum spread between units of $0.44{ }^{\circ} \mathrm{C}$. Data were typically recorded for a full day of HVAC operation, with a data collection interval of one minute or less.

Based on the measured temperatures, values of cumulative duct system conduction effectiveness (Delp et al. 1997) were calculated using the equation:

$$
\varepsilon\left(t^{\prime}\right)=\frac{\int_{0}^{t^{\prime}}\left[T_{\text {register }}(t)-T_{\text {room }}(t)\right] d t}{\int_{0}^{t^{\prime}}\left[T_{\text {supply-plenum }}(t)-T_{\text {room }}(t)\right] d t}
$$


where $t^{\prime}$ is the time elapsed during the measurements, $\mathrm{t}$ is the time variable, $T_{\text {register }}$ is the temperature of air exiting a supply register, $T_{\text {room }}$ is the room air temperature, and $T_{\text {supply-plenum }}$ is the average temperature of air immediately downstream of the cooling coil. If the supply fan is downstream of the cooling coil, the average temperature downstream of the fan is substituted for

$T_{\text {supply-plenum. }}$ The conduction effectiveness represents the cooling capacity of the air delivered out of the supply register relative to the cooling capacity expected with no conduction heat gains to the supply duct.

\section{Isolation of Sections of Ductwork}

To measure the effective leakage area (defined subsequently) of sections of duct systems, subsections of entire ducts systems were isolated (sealed off) from the remainder of the duct system and from the indoor air. A variety of methods of sealing supply-air registers were evaluated in the laboratory. The most practical method identified was to seal the outlet of registers with large adhesive-coated plastic films (e.g., 3M, Duct Mask).

To block cross sections of duct interiors, access hatches were cut in ducts, then polystyrene or cardboard panels were taped in place to seal the duct cross section and sheet metal cover plates were installed and sealed over the access hatches.

\section{Duct system Effective Leakage Area (ELA) Measurements}

To characterize the leaks in an isolated section of duct work, the ELAs of duct sections were measured using fan-pressurization procedures that are commonly employed to characterize leaks in building envelopes. The ELA is the area of a single orifice that would leak air at the same rate as all the leaks in the section of duct system at a reference pressure difference. ELAs in ducts are usually determined for a $25 \mathrm{~Pa}$ reference pressure $\left(P_{\text {ref }}\right)$ across the leaks.

The ELA measurement protocol, illustrated in Figure 1, is described in detail elsewhere (Delp et al. 1997, ASTM 1987) and very similar to the procedure described by SMACNA (1985). The basic procedure is to use a variable-speed fan with an integral air flow meter (Energy Conservatory, Minneapolis Duct Blaster) to inject air into the isolated section of duct at various flow rates while monitoring the pressure difference between the interior and exterior of the duct. Flow rates and simultaneous pressure differences are recorded for a range of pressure differences between 10 and approximately $100 \mathrm{~Pa}$. The ELA and the pressure exponent, $n$, are then determined by fitting the following equation to the data

$$
E L A=Q \sqrt{\rho / 2}\left[\frac{\Delta P_{r e f}{ }^{(n-0.5)}}{\Delta P^{n}}\right]
$$

where $Q$ is the air flow rate, $\rho$ is the air density, and $\Delta P_{\text {ref }}$ is the reference pressure, usually $25 \mathrm{~Pa}$. The pressure exponent typically has a value near 0.6 . With uncertainties in measured air 
injection rates ${ }^{3}$ of approximately $\pm 5 \%$ and in average measured pressure across leaks ${ }^{4}$ of approximately $\pm 2.0 \mathrm{~Pa}$, the estimated uncertainty in the ELA, determined from parametric calculations, is $\pm 10 \%$.

To allow comparisons among buildings, duct system ELAs were normalized by the floor area served by the duct system or by the surface area of the ductwork. For each system, the duct leakage class (ASHRAE 1997, chapter 32) was also calculated. The leakage class is defined by the equation

$$
C_{L}=710 F / \Delta P^{0.65}
$$

where $\mathrm{F}$ is the leakage flow rate in $\mathrm{L} \mathrm{s}^{-1}$ per square meter of duct surface area, and $\Delta \mathrm{P}$ is the pressure difference during the leakage measurement. The duct leakage class is defined as the airleakage rate per $9.3 \mathrm{~m}^{2}\left(100 \mathrm{ft}^{2}\right)$ of duct surface area with a $250 \mathrm{~Pa}(1.0 \mathrm{iwg})$ pressure difference across the leaks, expressed in units of cfm. ASHRAE (1997, chapter 32) lists attainable leakage classes ranging from 3 to 12 , "for quality construction and sealing practices" but notes that these attainable leakage classes do not account for leakage at connections to grilles or diffusers, access doors, and other duct-mounted equipment. For unsealed ducts, ASHRAE (1997, chapter 32) provides predicted leakage classes of 30 to 48 .

\section{Duct System Pressure Measurements}

Duct system ELAs may be used in conjunction with duct-system static pressures during HVAC system operation to estimate rates of air leakage from ducts. In constant-volume HVAC systems, static pressures are constant and were measured at multiple locations in the duct work a single time using electronic pressure transducers with a $0.1 \mathrm{~Pa}$ resolution (Energy Conservatory: Minneapolis Pressure \& Fan Flow Gauge, Model DG3 or Automatic Pressure Transducer). In VAV HVAC systems, the static pressures were measured for a range of fan speeds and VAV damper positions.

\section{Measurement of Rates of Air Flow through Supply Registers}

Traditionally, rates of air flow through supply registers are measured by air balance companies using commercially available air-flow hoods. These instruments direct the air exiting a supply register past a measurement station that determines the velocity pressure at multiple locations. Measurement errors result from low, inaccurately measured velocity pressures when register air flow rates are low, and from highly nonuniform velocities at the flow measurement station. Also, air-flow hoods can cause the flow rate during the measurement to be less than the undisturbed flow rate. Both published literature and our laboratory tests confirmed that excessive (e.g., 25\%) measurement errors can occur under some conditions (ASHRAE 1988, Foltz 1984).

\footnotetext{
${ }^{3}$ The manufacturer's rated accuracy of the flow sensor integral to the fan is $\pm 3 \%$; however, we have assumed a $5 \%$ uncertainty to account for fluctuations in the pressure difference at the flow sensor.

${ }^{4}$ Static pressures in the duct system during the ELA measurement may vary slightly with location. We estimate that the true average pressure drop across leaks in the duct may vary by $\pm 2 \mathrm{~Pa}$ from the average measured static pressure in the duct during the ELA measurements.
} 
To measure flow through supply registers more accurately, we used a fan-powered flow hood, as illustrated in Figure 2. Air exiting the register passes through a collection hood, then through a duct connected to a variable-speed fan with an integral flow meter (Energy Conservatory, Minneapolis Duct Blaster). The fan speed was adjusted via manual or computer control to maintain a static pressure difference of zero between the interior of the collection hood and room air. The flow rate was determined with the flow meter system integral to the fan. With this measurement method, the velocity profile at the flow meter is unaffected by the supply register and the velocity pressure at the flow meter was maintained high enough for accurate measurements of flow rate. By maintaining the static pressure in the collection hood equal to $0 \pm$ $0.5 \mathrm{~Pa}$, the measurement system should change the rate of air flow through the supply register only marginally. Sensitivity studies at one building indicated that an individual register flow rate changed by less than $1 \%$ as the static pressures in the hood deviated from zero by $\pm 0.5 \mathrm{~Pa}$.

When flow rates through multiple supply registers are summed, there should be no bias ${ }^{5}$ in the sum of all register flows due to the influence of the measurement system on the measured register flow rates at individual registers. Thus, the uncertainty in the sum of register flow rates is primarily due to the bias in measurement of flow rate through the calibrated fan, estimated to be $\pm 5 \%$. Air leakage at the junction of the supply register with the air collection hood could increase this uncertainty; however, the amount of leakage should be small because the pressure difference across this junction is nearly zero (i.e., $\pm 0.5 \mathrm{~Pa}$ ).

\section{Measurement of Air Flow Rates At Duct Cross Sections}

Velocity Traverses: Two methods were used to measure the rates of air flow at duct cross sections. When, a sufficient length (e.g., > 10 diameters) of straight ductwork was present upstream of the cross section, the flow rate was determined from a velocity traverse ${ }^{6}$ made with a hot-wire anemometer. [Traverse procedures are described by SMACNA (1983) and ASHRAE (1997).] The accuracy of this method depends on the uniformity of velocities at the cross section and on the accuracy of the hot-wire anemometer. Generally, this measurement approach was precluded due to the absence of straight sections of ductwork upstream of the desired measurement location.

Tracer gas Method: In two buildings, we also experimented with the use of a tracer gas procedure to measure the rate of air flow inside a duct. The basic approach was to inject (at one or more locations) sulfur hexafluoride tracer gas into the duct system at a constant and measured rate, to measure the increase in tracer gas concentration in the airstream, and to calculate the air flow rate from a simple mass-balance equation. If the air handling unit (AHU) recirculated air, a more complex procedure with measurements during and immediately after tracer gas injection is required (Delp et al. 1996). The tracer gas measurements were made with an infrared analyzer calibrated at the measurement site. The major obstacle to these measurements was poor mixing of tracer in the airstream between the location of tracer injection and the downstream location

\footnotetext{
${ }^{5}$ The pressures at the register outlet are not biased positively or negatively during the measurements with a fanpowered flow hood.

${ }^{6}$ The velocities in the ducts were too low for accurate measurements with a Pitot tube, i.e., the resultant velocities pressures were only a few $\mathrm{Pa}$.
} 
where tracer gas concentration was measured. Mixing was checked by collecting and analyzing samples from multiple downstream locations inside the duct. In one building, a large axial fan (approximately $0.7 \mathrm{~m}$ in diameter) was installed in the duct to promote mixing, resulting in concentrations about $4 \mathrm{~m}$ and further downstream of the mixing fan that were uniform within approximately $3 \%$. However, immediately downstream of the mixing fan, tracer gas concentrations were still highly non-uniform. In another building, the tracer gas was injected upstream of the AHU fan and several hours of work were necessary to adjust the tracer injection process and obtain adequate downstream tracer mixing.

Uncertainties in these air flow rate measurements are due to uncertainties in tracer gas concentration measurements, uncertainties in the tracer injection rate measurements, and imperfect mixing of the tracer gas in the air. With proper selection and calibration of instruments, the uncertainty in the first two of these parameters can be as low as approximately 3\%. The mass-balance calculation requires estimates of tracer-gas concentrations in the airstreams, with perfect mixing between the tracer and the air. The extent of tracer-gas mixing will vary with the application and can be estimated based on the variability of the multipoint tracer-gas measurements. In highly favorable circumstances, one might have uncertainties of 3\% for tracer concentration measurement, $3 \%$ for tracer injection rate measurement, and $5 \%$ due to an imperfect characterization of the well-mixed tracer concentration downstream of the injection point. Based on the square root of the sum of the squares of these individual uncertainties, the overall uncertainty would be $\pm 7 \%$. If the AHU recirculates air (which is very common) and the more complex measurement procedure is required, the uncertainties in the measured air flow rate will be larger.

\section{Measurement of Air-leakage Rates in Duct Systems}

As described subsequently, accurate measurements of the rates of air leakage in duct systems are inherently very difficult. Therefore, in this study we intercompared the following three basic approaches for measuring these air-leakage rate.

Air Leakage Estimated from ELA and Pressure: The first method of estimating rates of air leakage is to calculate $Q$ using equation (1) with the measured pressure exponent $(n)$ and the temporal and spatial average static pressure in the duct system during normal HVAC system operation as inputs. Because the static pressures in duct systems vary significantly with location along the flow path and the locations of leaks are unknown, this approach can only provide an estimate of the air-leakage rate. Walker et al. (1998) have used essentially the same method to measure air leakage from residential ducts, and they estimated that the maximum uncertainty was $40 \%$ of the measured air-leakage rate.

Air Leakage Estimated from Upstream Duct Flow and Register Flows: The second method of estimating the rate of air leakage from a section of ductwork was to measure the air flow rate at a cross section in the ductwork (using the hot-wire traverse or tracer gas method), measure rates of air flow through all downstream supply registers, and then subtract the sum of the register flow rates from the upstream flow rate at the duct cross section. The main limitation to this approach was that the expected difference between the upstream flow rate and sum of register flow rates was comparable in magnitude to the measurement uncertainty. In nearly ideal circumstances, we 
might expect a 5\% uncertainty in both the total register flow rate and the upstream duct flow. Thus a measured $20 \%$ rate of air leakage might have error bounds of \pm 9 percentage points, i.e., the measured rate of air leakage would be between $11 \%$ and $29 \%$.

This measurement approach can not be used routinely in VAV HVAC systems because the supply-air flow rates are likely to change during the period of register flow rate measurements.

Air Injection and Register Flow Method of Measuring Air-leakage Rates: As indicated in the previous discussion, inaccurate measurements of rates of air flow at duct cross sections are an obstacle to the characterization of air-leakage rates in sections of ductwork. To overcome this barrier, a new approach was developed as illustrated in Figure 3. The first step was to estimate the rate of air flow at the most upstream location of the section of ductwork based on standard air-flow hood measurements or air-balance reports. Alternately, the static pressure was measured a few meters downstream of this location. Then, the section of ductwork under consideration was isolated from the upstream ductwork as described previously and a variable-speed fan with integral flow meter was used to inject air into the section of ductwork. The air-injection rate was adjusted as needed to produce the estimated normal rate of air flow in the duct or to reproduce the normal static pressure at the reference location. Thus; the air-injection process recreated a normal air flow rate and pressure in the section of ductwork and this air flow rate was determined with reasonable accuracy via the integral flow meter. During the period of air injection, the register flow rates were measured using the fan-powered air flow hood method. Finally, the airleakage rate was determined by subtracting the sum of the register flow rates from the airinjection rate.

This approach can be applied almost universally because there is no need for straight sections of ductwork or conditions that mix tracer gas. It can even be used to characterize air-leakage rates in VAV HVAC systems for a range of supply-air flow rates, as long as the VAV controllers are temporarily deactivated. Measurement uncertainties remain high, but comparable to the most accurate measurements made with other methods. Assuming 5\% uncertainties in both the airinjection rate and in the sum of supply register flow rates, the maximum measurement uncertainty in the air-leakage rate would be approximately $\pm 10 \%$ of the rate of air flow rate in the duct system, which might still be a large fraction of the air leakage rate. One caution must be provided: in one of two buildings, the air-injection process dislodged particles from the duct interior that were transported out of downstream supply registers and deposited on desks and office equipment, causing significant soiling of surfaces. Experiments are planned to evaluate methods of eliminating this problem.

\section{RESULTS}

\section{Physical characteristics of supply ducts}

Table 1 summarizes the compilation of physical characteristics of sections of supply-air duct systems in four buildings with VAV HVAC systems, one building with a constant-volume dualduct system, and three sections of ductwork in one building with a constant-volume single-duct

HVAC system. In five of six buildings, the supply ducts were located in a ceiling plenum. The 
ductwork was exposed to the occupied space and located near the ceiling in the sixth building. In two buildings, the characterized sections of supply ductwork were fully insulated with a $2.5 \mathrm{~cm}$ or $5 \mathrm{~cm}$ thickness of external fiberglass insulation, except for short sections of ductwork connected to supply registers. Ducts in two buildings were partially insulated. The available design documents for two buildings contained no reference to thermal insulation. Duct crosssectional dimensions ranged from $0.15 \mathrm{~m}$ to $1.6 \mathrm{~m}$. Maximum path lengths for the air flow within a building floor ranged from $24 \mathrm{~m}$ to $74 \mathrm{~m}$. The surface area of supply ductwork was $27 \%$ to $43 \%$ of the floor area served by the duct system. In VAV ventilation systems, the ducts downstream of the VAV control units accounted for $50 \%$ to $75 \%$ of the total duct surface area. Air velocities calculated from the maximum flow in the duct section and the largest (furthest upstream) duct cross section ranged from 2.8 to $24 \mathrm{~m} \mathrm{~s}^{-1}$. In the four sections of ductwork where static pressures were measured, maximum static pressures ranged from $23 \mathrm{~Pa}$ to $270 \mathrm{~Pa}$. The floor area served per supply register ranged from 16 to $41 \mathrm{~m}^{2}$.

\section{Duct Effective Leakage Areas, Leakage Classes, and Static Pressures}

ELAs and static pressures were measured in four total sections of ductwork within two buildings, and the results are summarized in Tables 2 and 3. In building 5, the ELAs of the three sections of supply ductwork ranged from 1.5 to $2.0 \mathrm{~cm}^{2}$ per square meter of floor area served, and from 4.1 to $4.8 \mathrm{~cm}^{2}$ per square meter of duct surface area. In Building 6, the normalized ELAs of the duct system were much smaller, $0.4 \mathrm{~cm}^{2}$ per square meter of floor area served and $1.0 \mathrm{~cm}^{2}$ per square meter of duct surface area. Approximately two-thirds of the ELA in Building 6 was from the sections of ductwork downstream of the VAV control units; however, most of the estimated air leakage was upstream of the VAVs because of the higher upstream static pressures.

Duct leakage classes ranged from 230 to 270 for the three sections of ductwork in Building 5 . In Building 6, the duct leakage class of the entire duct system was 60 . The sections upstream and downstream of the VAV boxes of Building 6 had leakage classes of 110 and 48, respectively. These measured leakage classes are much higher than the leakage classes attainable for quality duct construction and sealing practices of 3 to 12 as published by ASHRAE (1997, Chapter 32). ASHRAE's published "attainable" leakage classes do not account for leakage at connections to grilles or diffusers, access doors, and other duct-mounted equipment.

Static pressures in Building 5 ductwork varied with time because the supply fan was under control of a variable-speed drive and a carbon dioxide sensor. All of the measured static pressures were quite low, ranging from 23 to $57 \mathrm{~Pa}$ at the most upstream section of ductwork and from 1 to $12 \mathrm{~Pa}$ near the furthest downstream supply register. However, we only characterized the static pressures (and ELAs) of horizontal sections of ductwork located on a single floor. Static pressures were higher in upstream sections of ductwork, such as the ducts in the fan rooms and the vertical ducts between the fans and the floors.

In Building 6, duct static pressures varied with the position of the dampers in the VAV control units and also with changes in fan speed, controlled by a variable-speed drive. With the VAV dampers half open ( $45^{\circ}$ position), static pressures upstream of the VAV control units ranged from $270 \mathrm{~Pa}$ at maximum fan speed to $130 \mathrm{~Pa}$ with a $40 \mathrm{hz}$ setting on the variable-speed drive. Downstream of a VAV control unit, static pressures were much lower ( 8 to $15 \mathrm{~Pa}$ ). 


\section{Estimated Rates of Air Leakage from Ducts}

Table 4 provides the estimated rates of air leakage from the duct systems. In the NE duct of Building 5 and the ducts of Building 6, air-leakage rates were estimated using all three of the procedures described previously. In the SE duct of Building 5, two out of three methods were used to estimate air-leakage rates. The estimated air-leakage rates as a percentage of the inlet air flow rate varied widely from $0 \%$ to approximately $30 \%$, with most of the estimates falling between $10 \%$ and $20 \%$.

If the measurement methods were perfect, all of the percentage leakage rates for particular duct systems should be identical. However, due to the difficulty of performing sufficiently accurate measurements, percentage leakage rates of the same section of ductwork based on the different measurement procedures varied by $2 \%$ to $21 \%$ of the inlet air flow (often by a factor of 1.5 to 3 ). The method of estimating air-leakage rates from measured ELAs and the average of upstream and downstream duct static pressures yielded the highest estimates of air leakage (15\% to $30 \%$ ).

\section{$\underline{\text { Supply-air Temperature Gains and Conduction Effectiveness }}$}

Air temperature increases in the supply ducts, between the cooling coils and the supply registers, were monitored ${ }^{7}$ in a San Francisco office building, a university campus building, and in ductwork within Building 6. Each of these buildings used VAV ventilation systems. The average increases in supply-air temperature between the outlet of the cooling coils and the supply registers are shown in Figure 4. In the San Francisco office building, the temperature increase averaged about $0.6^{\circ} \mathrm{C}$ and was not correlated with duct length. In the university office and classroom building, the temperature rise was typically about $1.2^{\circ} \mathrm{C}$, but was $3.0^{\circ} \mathrm{C}$ in the worst case when the temperature exiting the cooling coil was lowest (approximately $12^{\circ} \mathrm{C}$ ). Again, the temperature rise was not correlated with duct length. In Building 6, the air-temperature rise between the roof-top air handler and the supply registers did increase with increasing supply duct length from $1.4{ }^{\circ} \mathrm{C}$ to $2.1{ }^{\circ} \mathrm{C}$, as illustrated in Figure 4 .

Values of cumulative conduction effectiveness for the duct systems are also plotted in Figure 4. Values of cumulative conduction effectiveness are not highly correlated with the supply air temperature gain because the temperature of air exiting the cooling coils varies among the buildings. For the San Francisco office building and the university campus building, the conduction effectiveness is an average based on temperatures at six and ten supply registers, respectively. For Building 6 , independent values of cumulative conduction effectiveness are plotted for three supply registers. The cumulative conduction effectiveness ranged from 0.75 to 0.90 ; thus, heat conduction decreased the cooling capacity of the supply air exiting registers by $10 \%$ to $25 \%$.

\footnotetext{
7 The San Francisco office building and university campus building were distinct from Buildings 01-06 described in Table 1. The temperature measurements in Building 6 were not performed within the same section of ductwork characterized in Table 1.
} 
Figure 5 illustrates a time history of the measured air temperatures and cumulative conduction effectiveness. Because the air temperatures cycle with approximately a $2^{\circ} \mathrm{C}$ range (presumably due to modulation in the rate of chilled water flow through the cooling coil), the cumulative conduction effectiveness must be based on measurements over a period of many cycles.

We attempted to measure air temperature decreases in supply ducts of Building 5 , between locations just downstream of heating coils and the further downstream supply registers. However, the air temperature downstream of the heating coil was very non-uniform, preventing an accurate determination of the air temperature decreases and associated conduction effectiveness. The large spatial variation in air temperature downstream of heating coils may be a consequence of the large change in hot water temperature as it flows through a heating coil (approximately 10 to $50^{\circ} \mathrm{C}$ ). In contrast, temperature increases in chilled water flowing through cooling coils are typically much smaller (e.g., $\left.<10^{\circ} \mathrm{C}\right)$.

\section{DISCUSSION}

Prior research on the performance of duct systems in large commercial buildings is very limited. Barriers to research in this area include the large size and high degree of complexity of these duct systems and inadequately developed research methods. Additionally, there has been a fairly widespread belief among building professionals that these ducts have low rates of air leakage and, in any event, that leakage does not substantially influence HVAC energy use because the ducts are located within the conditioned space. These beliefs appear to be unsupported by data. This study has found that at least some large commercial duct systems have significant air leakage. The influence of air leakage on HVAC energy use is being investigated via modeling (Franconi et al 1998) and appears to be very significant even with ducts located in the conditioned space.

We have obtained some of the first data on the performance of duct systems in US large commercial buildings. Because we have only performed studies in a few buildings, general conclusions are premature. Our findings, as discussed below, are only suggestive with respect to typical duct system performance in large commercial buildings.

We found that supply ducts systems have a surprising large surface area, approximately $30 \%$ to $40 \%$ of building floor area. In the VAV systems, $50 \%$ to $75 \%$ of the surface area was associated with ducts downstream of VAV control units. Therefore, focusing energy conservation efforts only on the ductwork upstream of VAVs is not appropriate. For example, duct leakage tests implemented within new buildings have often involved only the ductwork upstream of VAV control units. These tests may miss much of the leakage.

The leakage areas of the supply ducts in these large commercial buildings was 0.4 to $2 \mathrm{~cm}^{2}$ per square meter of floor area, which is comparable to that in residences and somewhat lower than found in light-commercial buildings. The measured duct leakage class ranged from 60 to 270 , which is far higher (more leaky) than the leakage classes of 3 to 12 listed by ASHRAE (1997) as attainable for quality duct construction and sealing practices. The measured duct leakage classes also exceeded ASHRAE's default values of 30 to 48 for unsealed ducts. The ASHRAE estimates 
do not account for leakage at connections to grilles or diffusers, access doors, and other ductmounted equipment. Based on inspections, we suspect that much of the effective leakage area was located at these connections and within the duct-mounted components such as supply registers. Consequently, it appears that greater attention should be directed at the leakage of entire duct systems, including the leakage at all connections and components.

Rates of air leakage from duct systems are difficult to measure accurately. Most of our measurements indicated a $10 \%$ to $20 \%$ leakage rate; however, percentage leakage rates of the same section of ductwork based on the different measurement procedures varied by $2 \%$ to $21 \%$ of the inlet air flow (often by a factor of 1.5 to 3 ). The inconsistencies among the results of different measurement procedures exemplify the need for further development and evaluation of measurement methods.

Our new approach for measuring air-leakage rates in duct systems, using fans with integral air flow meters to inject air at a measured rate and subtracting the sum of register flows measured with a fan-powered flow hood, appears to be the most promising, broadly applicable measurement procedure. The magnitudes and profiles of velocity at the air flow meters can be maintained in a range that results in a relatively high measurement accuracy, leading to an uncertainty in air leakage rates equal to about $10 \%$ of the of the nominal rate of air flow in the duct system. However, existing air injection fans with integral flow meters can not produce the high flow rates and static pressures normally experienced in some sections of ductwork. In these situations, the measured rate of air leakage must be scaled up to a predicted rate of air leakage that applies for typical HVAC operating conditions. For future measurements, convenient fans and flow meters with a higher maximum flow rate and pressure could be developed.

Estimating air-leakage rates from the duct systems based on ELAs and the average static pressures measured at the most upstream and downstream locations within the duct yielded the highest estimates of air-leakage rates. Possibly, this method overestimates air-leakage rates because much of the leakage area is located in the sections of ductwork and in duct components (particularly supply registers) with below-average static pressures. Air-leakage estimates based on this method will remain uncertain, because we cannot determine the locations of leaks and the pressure differences across these leaks.

Heat gains between the outlet of cooling coils and the supply registers caused supply-air temperatures to increase, in general, by $0.6{ }^{\circ} \mathrm{C}$ to $2{ }^{\circ} \mathrm{C}$. While these temperature increases seem to be small, the corresponding values of conduction effectiveness were 0.75 to 0.90 . Thus, heat conduction to the supply airstreams decreased the cooling capacity of the supply air exiting registers by $10 \%$ to $25 \%$. Quantifying, the influence of these conduction heat gains on HVAC energy use is one of our future research objectives.

\section{ACKNOWLEDGMENTS}

This work was supported by the Assistant Secretary for Energy Efficiency and Renewable Energy, Office of Building Technology and Community Systems, of the US Department of 
Energy under Contract No. DE-AC03-76SF00098 and by the California Institute For Energy Efficiency. This paper benefited from the review comments of lain Walker and Tim Salsbury.

\section{REFERENCES}

ASHRAE (1988) ASHRAE Standard 111-1988, Practices for Measurement, Testing, Adjusting, and balancing of Building Heating, Ventilation, Air Conditioning, and Refrigeration Systems, American Society of Heating, Refrigerating, and Air Conditioning Engineers, Atlanta.

ASHRAE (1997) 1997 ASHRAE Handbook, Fundamentals, American Society of Heating, Refrigerating, and Air Conditioning Engineers, Atlanta.

ASTM (1987) "ASTM E-779-87, Standard test method for determining air leakage rate by fan pressurization", American society for testing and materials, Philadelphia, PA.

Delp, WW, NE Matson, MP Modera, (1998) "Exterior exposed ductwork: delivery effectiveness and efficiency", ASHRAE Transaction 104(2): 709-721

Delp, WW, NE Matson, E Tschudy, MP Modera, and RC Diamond (1998) "Field investigation of duct system performance in light commercial buildings", ASHRAE Transactions 104(2): $722-733$.

Delp, WW, NE Matson, DJ Dickerhoff, and MP Modera (1998) "Field investigation of duct system performance in light commercial buildings (round 2)", Proceedings of the 1998 ACEEE Summer Study on Energy Efficiency, in Buildings, pp. 3.105-3.116, American Council for an Energy Efficient Economy, Washington, DC.

Foltz, DF (1984) "The systematic and random errors of portable airflow balancing instrumentation with various ventilation system fittings", ASHRAE Transactions 90(2B): 627-644.

Franconi, E., W.W. Delp, and M.P. Modera (1998) "Impact of Duct Air-Leakage on VAV System Energy Use, LBNL-42417, Lawrence Berkeley National Laboratory, Berkeley, CA. submitted to Energy and Buildings.

Levinson, R., W. Delp, D. Dickerhoff, W Fisk, M. Nematollahi, I Stordahl, C Torre, D Wang, R Diamond, and M Modera (1997) "Commercial thermal distribution systems: Final report for California Institute for Energy Efficiency", LBNL-41045, Lawrence Berkeley National Laboratory, Berkeley, CA.

Modera, MP, WJ Fisk, WW Delp, R Levinson, and O. Brzozowski (1998) "Sealing ducts in large commercial buildings with aerosolized sealant particles", LBNL-42414, Lawrence Berkeley National Laboratory, Berkeley, CA, submitted to Energy and Buildings.

SMACNA (1983) "HVAC air duct leakage test manual", Sheet Metal and Air Conditioning Contractors National Association, Inc., Tysons Corner, Vienna, Virginia.

SMACNA (1983) "HVAC systems: testing, adjusting, and balancing", Sheet Metal and Air Conditioning Contractors National Association, Inc., Tysons Corner, Vienna, Virginia.

Walker, I, M Sherman, M Modera, and J Siegel (1998) "Leakage diagnostics, sealant longevity, sizing and technology transfer in residential thermal distribution systems", LBNL-41118, Lawrence Berkeley National Laboratory, Berkeley, CA. 
Table 1. Physical characterization of sections of supply-air duct systems in large commercial buildings. Data for buildings L-01 through L-04 were determined from a review of plans. Data from Buildings L-05 and L-06 were determined from inspections and measurements.

\begin{tabular}{|c|c|c|c|c|c|c|c|c|}
\hline BUILDING & L-01 & L-02 & L-03 & L-04 & L-05 & L-05 & $L-05$ & L-06 \\
\hline Year (from plans) & 1988 & 1995 & 1971 & 1981 & 1959 & 1959 & 1959 & $1965 \#$ \\
\hline Space Description & $\begin{array}{c}\text { 3rd floor, SE } \\
\text { quad }\end{array}$ & $\begin{array}{c}\text { 2nd fl, SW \& S- } \\
\text { center }\end{array}$ & 3rd $f l$ north side & 3rd floor & $\begin{array}{l}\text { 3rd fl, SE } \\
\text { Perimeter }\end{array}$ & $\begin{array}{l}\text { 3rd fl, NE } \\
\text { Perimeter }\end{array}$ & $\begin{array}{l}\text { 3rd fl, NW } \\
\text { Perimeter }\end{array}$ & $\begin{array}{l}\text { Section of } \\
\text { Basement }\end{array}$ \\
\hline Space Area $\left(\mathrm{m}^{2}\left[\mathrm{ft}^{2}\right]\right)$ & $1,400[15,000]$ & $2,800[30,000]$ & $3,400[37,000]$ & $25,000[18,000]$ & $220[2360]$ & 280 [3040] & $360[3840]$ & $469[5050]$ \\
\hline \multicolumn{9}{|l|}{ SUPPLY-AIR SYSTEM } \\
\hline Type & VAV & VAV w/reheat & dual duct & VAV w/reheat & CAV w/reheat* & CAV w/reheat $^{\star}$ & CAV w/reheat* & VAV \\
\hline Max Flow in Duct Section(L/s [cfm]) & $7980[16900]$ & $13,600[28,800]$ & $13,000[27,000]$ & $6670[14100]$ & 750 [1590] & $1110[2360]$ & Not available & $1900[4000]$ \\
\hline Max Static Press (Pa [iwg]) & $870[3.5]+$ & $620[2.5]+$ & $1,200[4.75]+$ & $820[3.3]+$ & $57[0.23]$ & $23[0.09]$ & $37[0.15]$ & $270[1.1]$ \\
\hline Duct in Ceiling Plenum $(\mathrm{Y} / \mathrm{N})$ & $\bar{Y}$ & $\bar{Y}$ & $\bar{Y}$ & $\bar{Y}$ & $\bar{Y}$ & $\bar{Y}$ & $\bar{Y}$ & $\mathrm{~N}$ \\
\hline Duct Insulated? (Y/N/Part) & $\mathrm{N}$ & $P$ & $\bar{N}$ & $P$ & $\begin{array}{l}Y, 2.5 \mathrm{~cm} \\
\text { fiberglass }\end{array}$ & $\begin{array}{l}Y, 2.5 \mathrm{~cm} \\
\text { fiberglass }\end{array}$ & $\begin{array}{l}Y, 2.5 \mathrm{~cm} \\
\text { fiberglass }\end{array}$ & $\begin{array}{c}Y, 2.5 \text { and } 5.0 \mathrm{~cm} \\
\text { fiberglass }\end{array}$ \\
\hline Duct Surface Area $\left(\mathrm{m}^{2}\left[\mathrm{ft}^{2}\right]\right)$ & $379[4,075]$ & $894[9,619]$ & $1,003[10,796]$ & $481[5,174]$ & $77.6[835]$ & $108[1160]$ & $155[1660]$ & $176[1890]$ \\
\hline Duct:Floor Area (ratio) & 0.27 & 0.32 & 0.29 & 0.29 & 0.35 & 0.38 & 0.43 & 0.37 \\
\hline$\%$ Duct Area Upstream of VAVs & 49 & 31 & $\mathrm{NA}$ & 29 & NA & $\mathrm{NA}$ & $\mathrm{NA}$ & 24 \\
\hline$\%$ Duct Area Downstream of VAVs & 51 & 69 & NA & 71 & NA & NA & NA & 76 \\
\hline Max Duct Dim (cm [in]) & $71 \times 71[28 \times 28]$ & $114 \times 91[45 \times 36]$ & $140 \times 38[55 \times 15]$ & $163 \times 51[64 \times 20]$ & $107 \times 25[42 \times 10]$ & $91 \times 36[36 \times 14]$ & $107 \times 36[42 \times 14]$ & $122 \times 46[48 \times 18]$ \\
\hline Min Duct Dim++ (cm [in]) & $20 \times 15[8 \times 6]$ & $25[10]$ & $20[8]$ & $15[6]$ & $30 \times 15[12 \times 6]$ & $36 \times 20[14 \times 8]$ & $36 \times 20[14 \times 8]$ & $30 \times 25[12 \times 10]$ \\
\hline Max Flow Path Length (m [ft]) & $74[240]$ & $49[160]$ & $55[180]$ & $24[80]$ & $40.8[134]$ & $53.3[175]$ & $66.8[219]$ & $29.0[95]$ \\
\hline Air Velocity ${ }^{\star \star}\left(\mathrm{m} \mathrm{s}^{-1}\left[\mathrm{ft} \mathrm{min}^{-1-1}\right]\right)$ & $16[3100]$ & $14[2800]$ & $24[4700]$ & $8.0[1600]$ & $2.8[550]$ & $3.4[670]$ & NA & $3.4[670]$ \\
\hline \# VAV Units With Coils & 0 & 8 & 0 & 9 & NA & $\mathrm{NA}$ & NA & 0 \\
\hline \# VAV Units w/o Coils & 26 & 10 & 0 & 6 & NA & $\overline{N A}$ & $\mathrm{NA}$ & 4 \\
\hline Max VAV Inlet Diameter (cm [in]) & $38[15]$ & $46[18]$ & NA & $36[14]$ & NA & NA & NA & \\
\hline Min VAV Inlet Diameter (cm [in]) & $10[4]$ & $25[10]$ & NA & $15[6]$ & NA & NA & NA & \\
\hline \# Registers - Rectangular & 56 & 80 & 83 & 38 & 14 & 15 & 23 & 0 \\
\hline \# Registers - Linear & 0 & 8 & 0 & 14 & 0 & 0 & 0 & 0 \\
\hline \# Registers - Circular & 0 & 0 & 0 & 0 & 0 & 0 & 0 & 20 \\
\hline Floor Area per Register $\left(\mathrm{m}^{2}\left[\mathrm{ft}^{2}\right]\right)$ & $25[270]$ & $32[340]$ & $41[450]$ & $32[350]$ & $16[170]$ & $19[200]$ & $16[170]$ & $23[250]$ \\
\hline \# Fire/Smoke Dampers & 1 & 0 & 12 & 29 & 0 & 1 & 1 & 0 \\
\hline
\end{tabular}

\# Ducts installed approximately 1965 . VAV units installed approximately 1985

* No VAV control units; however, fan speed is controlled by a carbon dioxide sensor connected to a variable frequency drive.

+ Static pressure rating of fan at design flow, maximum pressures in the ducts are unavailable; $\quad$ ** Based on maximum flow and maximum (most upstream) duct section

++ Excludes flexible ducts 
Table 2. Measured supply-air duct system effective leakage areas, duct leakage classes, and static pressures in Building L-05.

\begin{tabular}{|l|c|c|c|}
\hline Building & 005 & 005 & 005 \\
\hline Year & 1959 & 1959 & 1959 \\
\hline Duct System Description & 3rd fl, SE Perimeter & 3rd fl, NE Perimeter & 3rd fl, NW Perimeter \\
\hline Measured Duct ELA $\left(\mathrm{cm}^{2}\right),[$ Pressure Exponent] & $320[0.62]$ & $520[0.58]$ & $710[0.58]$ \\
\hline ELA per Unit Floor Area $\left(\mathrm{cm}^{2} \mathrm{~m}^{-2}\right)$ & 1.5 & 1.9 & 2.0 \\
\hline ELA per Unit Duct Surface Area $\left(\mathrm{cm}^{2} \mathrm{~m}^{-2}\right)$ & 4.1 & 4.8 & 4.6 \\
\hline Duct Leakage Class & 230 & 270 & 260 \\
\hline Max. Measured Pressure in ducts (Pa [iwg]) & $57 \mathrm{~Pa}[0.23 \mathrm{iwg}]^{*}$ & $\begin{array}{c}23 \mathrm{~Pa}[0.09 \mathrm{iwg}] \text { at } \\
\text { maximum fan speed; } \\
14 \text { to } 19 \mathrm{~Pa}[0.06-0.08 \\
\text { iwg] during normal fan } \\
\text { operation }\end{array}$ & $37 \mathrm{~Pa}[0.15 \mathrm{iwg}]^{*}$ \\
\hline Min. Measured Pressure (Pa [iwg]) & $5.4 \mathrm{~Pa}[0.02 \mathrm{iwg}]^{*}$ & $\begin{array}{c}12 \text { Pa [0.05 iwg] at } \\
\text { maximum fan speed; } 8 \\
\text { to } 11 \text { Pa [0.03 - 0.04 } \\
\text { iwg] during normal fan } \\
\text { operation }\end{array}$ & \\
\hline
\end{tabular}

* At maximum fan speed. Fan speeds were at maximum during both the mid-morning and mid-afternoon measurement periods.

Table 3. Effective leakage areas, static pressures, and duct leakage class of supply-air ductwork in Building L-06.

\begin{tabular}{|c|c|c|c|c|c|c|c|c|c|c|}
\hline $\begin{array}{l}\begin{array}{l}\text { Section of System } \\
\text { Description }\end{array} \\
\end{array}$ & All Ducts & \multicolumn{3}{|c|}{ Upstream of VAVs } & $\begin{array}{c}\begin{array}{c}\text { Downstream } \\
\text { of VAV \#1 }\end{array} \\
\end{array}$ & $\begin{array}{c}\text { Downstream } \\
\text { of VAV \#2 }\end{array}$ & \multicolumn{3}{|c|}{$\begin{array}{l}\text { Downstream of } \\
\text { VAV \#3 }\end{array}$} & $\begin{array}{l}\text { Downstream } \\
\text { of All VAVs }\end{array}$ \\
\hline $\begin{array}{l}\text { Measured Duct ELA }\left(\mathrm{cm}^{2}\right) \\
\text { [Pressure Exponent] }\end{array}$ & $\begin{array}{c}186\left(195^{*}\right) \\
{[0.58]}\end{array}$ & \multicolumn{3}{|c|}{$\begin{array}{r}87 \\
{[0.61]} \\
\end{array}$} & $\begin{array}{c}10 \\
{[0.68]}\end{array}$ & $\begin{array}{c}32 \\
{[0.68]}\end{array}$ & \multicolumn{3}{|c|}{$\begin{array}{c}65 \\
{[0.64]}\end{array}$} & $\begin{array}{l}107 \\
{[---]}\end{array}$ \\
\hline $\begin{array}{l}\text { ELA per Unit Floor Area } \\
\left(\mathrm{cm}^{2} \mathrm{~m}^{-2}\right)\end{array}$ & 0.40 & \multicolumn{3}{|c|}{$\overline{----}$} & $-\ldots$ & $\overline{-\cdots}$ & \multicolumn{3}{|c|}{$\cdots$} & $\cdots$ \\
\hline Duct Leakage Classt & 60 & \multicolumn{3}{|c|}{120} & $-\cdots$ & $\overline{---}$ & \multicolumn{3}{|c|}{$\overline{-\cdots-}$} & 46 \\
\hline $\begin{array}{l}\text { ELA per Unit Duct Surface } \\
\text { Area }\left(\mathrm{cm}^{2} \mathrm{~m}^{-2}\right)\end{array}$ & $\begin{array}{c}1.05 \\
\left(1.10^{*}\right)\end{array}$ & \multicolumn{3}{|c|}{2.1} & 0.17 & 1.6 & \multicolumn{3}{|c|}{1.2} & 0.8 \\
\hline $\begin{array}{l}\text { Fan Speed as Frequency of } \\
\text { Variable-speed Drive (hz) }\end{array}$ & - & \multirow[t]{2}{*}{60} & \multirow[t]{2}{*}{50} & \multirow[t]{2}{*}{40} & - & $-\cdots$ & \multirow[t]{2}{*}{60} & \multirow[t]{2}{*}{50} & \multirow[t]{2}{*}{40} & \\
\hline & - & & & & - & & & & & \\
\hline $\begin{array}{l}\text { Measured Pressure }(\mathrm{Pa}) \\
{[\text { [iwg] }}\end{array}$ & - & $\left.\begin{array}{c}270 \\
{[1.08]}\end{array}\right]$ & $\begin{array}{c}215 \\
{[0.86]}\end{array}$ & $\begin{array}{c}134 \\
{[0.54]}\end{array}$ & - & $\cdots$ & $\begin{array}{c}15 \\
{[0.06} \\
\end{array}$ & $\begin{array}{c}12 \\
{[0.05]}\end{array}$ & $\begin{array}{c}8 \\
{[0.03]}\end{array}$ & \\
\hline
\end{tabular}

* The sum of the measured ELAs of the duct system sections is $195 \mathrm{~cm}^{2}, 5 \%$ higher than the directly measured ELA for the entire duct system.

+ Duct leakage class is based on the measured duct ELA at $25 \mathrm{~Pa}$ and the calculated leakage flow at $250 \mathrm{~Pa}$ static pressure, using the default pressure exponent of 0.65 (ASHRAE 1997). If the measured duct ELA at $25 \mathrm{~Pa}$ and the measured pressure exponents are used to calculate the leakage flow at $250 \mathrm{~Pa}$, the resulting values of leakage class are considerably different: 51 for all ducts, 110 for ducts upstream of VAVs, and 48 for ducts downstream of VAVs. 
Table 4. Estimates of rates of air leakage rate in supply duct systems as percent of upstream air flow rate.

\begin{tabular}{|c|c|c|c|}
\hline Building & L-05 & L-05 & L-06* \\
\hline Duct Section & $\begin{array}{l}\text { 3rd fl, SE } \\
\text { Perimeter }\end{array}$ & 3rd fl, NE Perimeter & $\begin{array}{l}\text { Basement Duct System Served } \\
\text { by Supply Fan } 14\end{array}$ \\
\hline \multicolumn{4}{|c|}{ Based on Subtracting the Sum of Supply Register Flow Rates from an Upstream Flow Rate } \\
\hline $\begin{array}{l}\text { Method of Measuring } \\
\text { Upstream Flow Rate }\end{array}$ & $\begin{array}{l}\text { Hot-wire } \\
\text { traverse }\end{array}$ & $\begin{array}{l}\text { Tracer Gas } \\
\text { method }\end{array}$ & Tracer Gas Method \\
\hline Air Leakage Rate & $9 \%++$ & $15 \%$ & $10 \%$ \\
\hline \multicolumn{4}{|c|}{$\begin{array}{l}\text { Based on Subtracting the Sum of Supply Register Flow Rates from the Rate of Air Injection into the Supply } \\
\text { Duct }\end{array}$} \\
\hline Air Leakage Rate & ---.---- & $13 \%$ & $4 \%+$ \\
\hline \multicolumn{4}{|c|}{$\begin{array}{l}\text { Calculated Based on Duct System ELA and Average of Upstream and Downstream Static Pressure } \\
\text { Measurements }\end{array}$} \\
\hline Air-leakage Rate & $30 \%$ & $20 \%$ & $15 \%$ \\
\hline
\end{tabular}

* Dampers in VAV boxes were $45^{\circ}$ open except dampers were fully open when the air injection and register flow method was used to measure the air leakage rate

+ Air injection fans had insufficient capacity to produce the normal air flow rate and static pressures in the duct system. The measured air-leakage rate was $4 \%$. Scaling up the measured air leakage rates to an estimated air leakage rate at normal operating pressures (using the pressure exponents from Table 3 ) also yielded a $4 \%$ air leakage rate. 


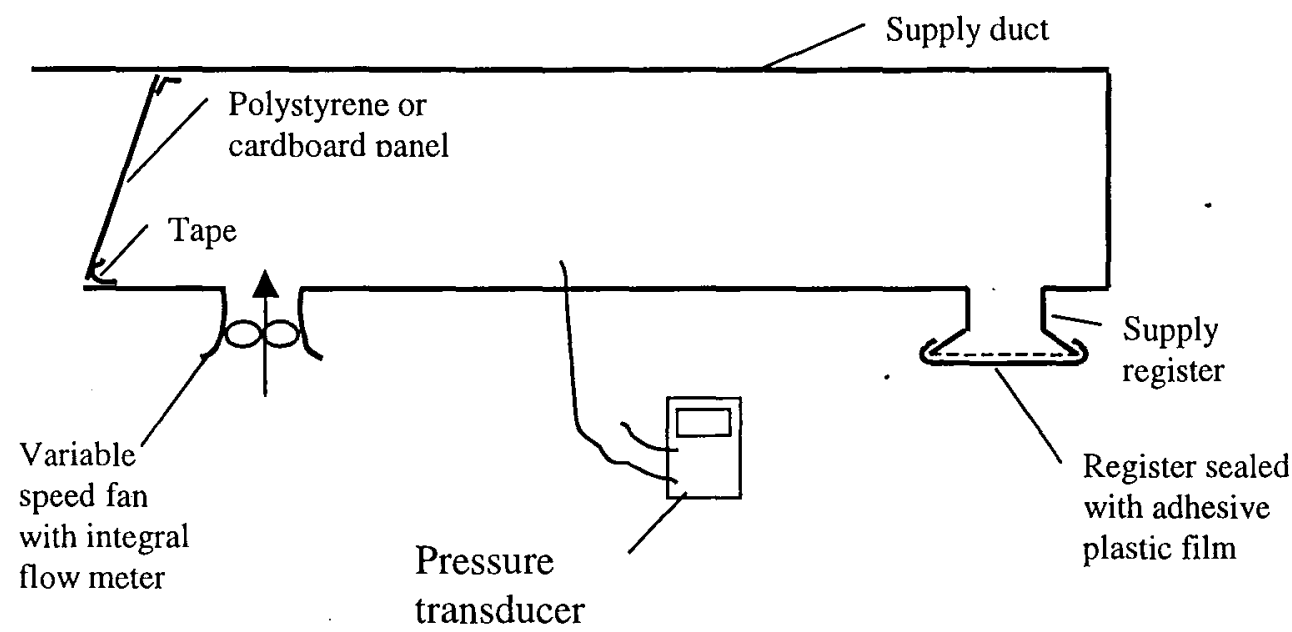

Figure 1. Illustration of apparatus used to measure duct system effective leakage area.

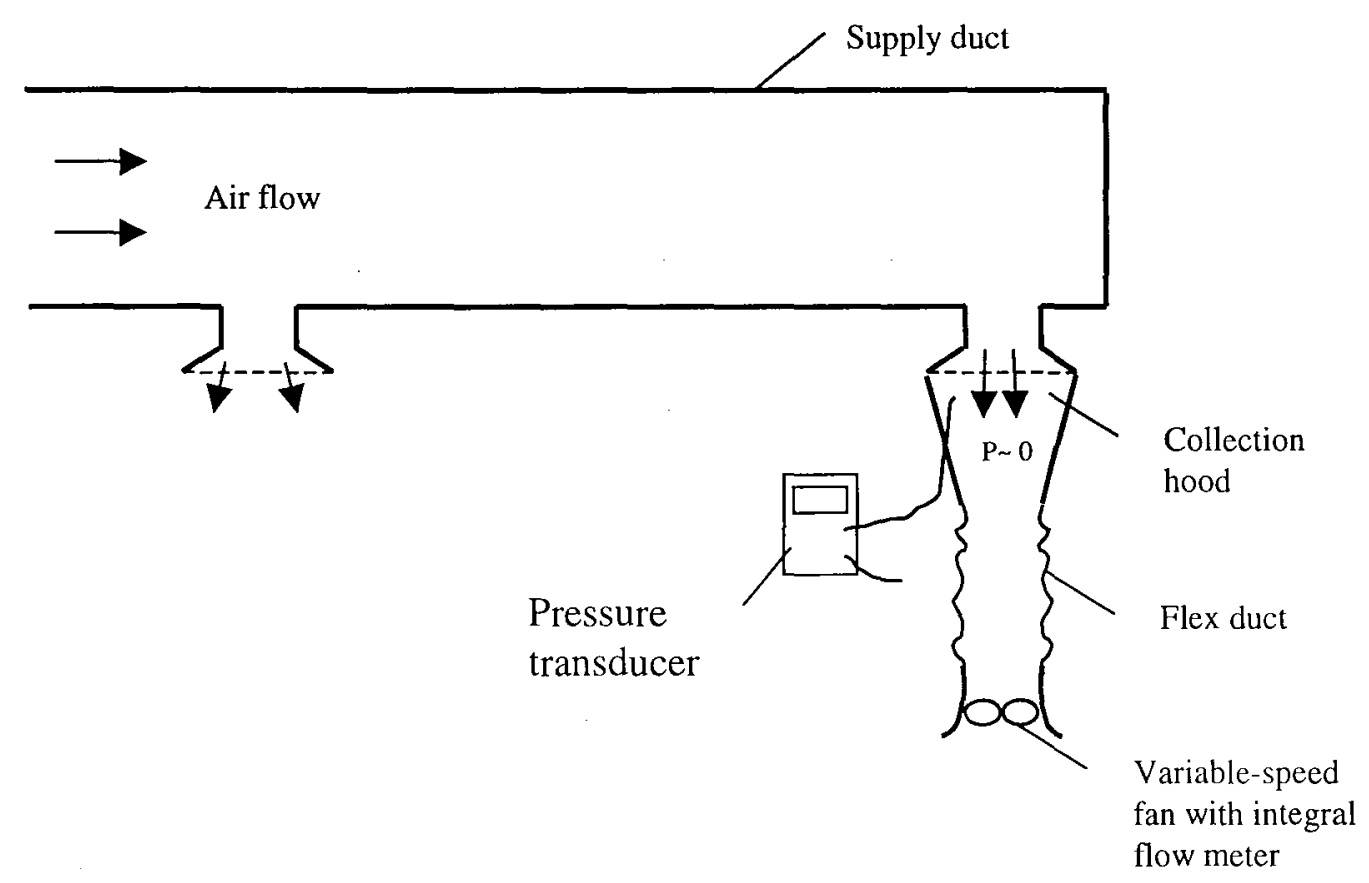

Figure 2. Illustration of system with fan-powered flow hood used to measure rates of air flow through supply registers. 


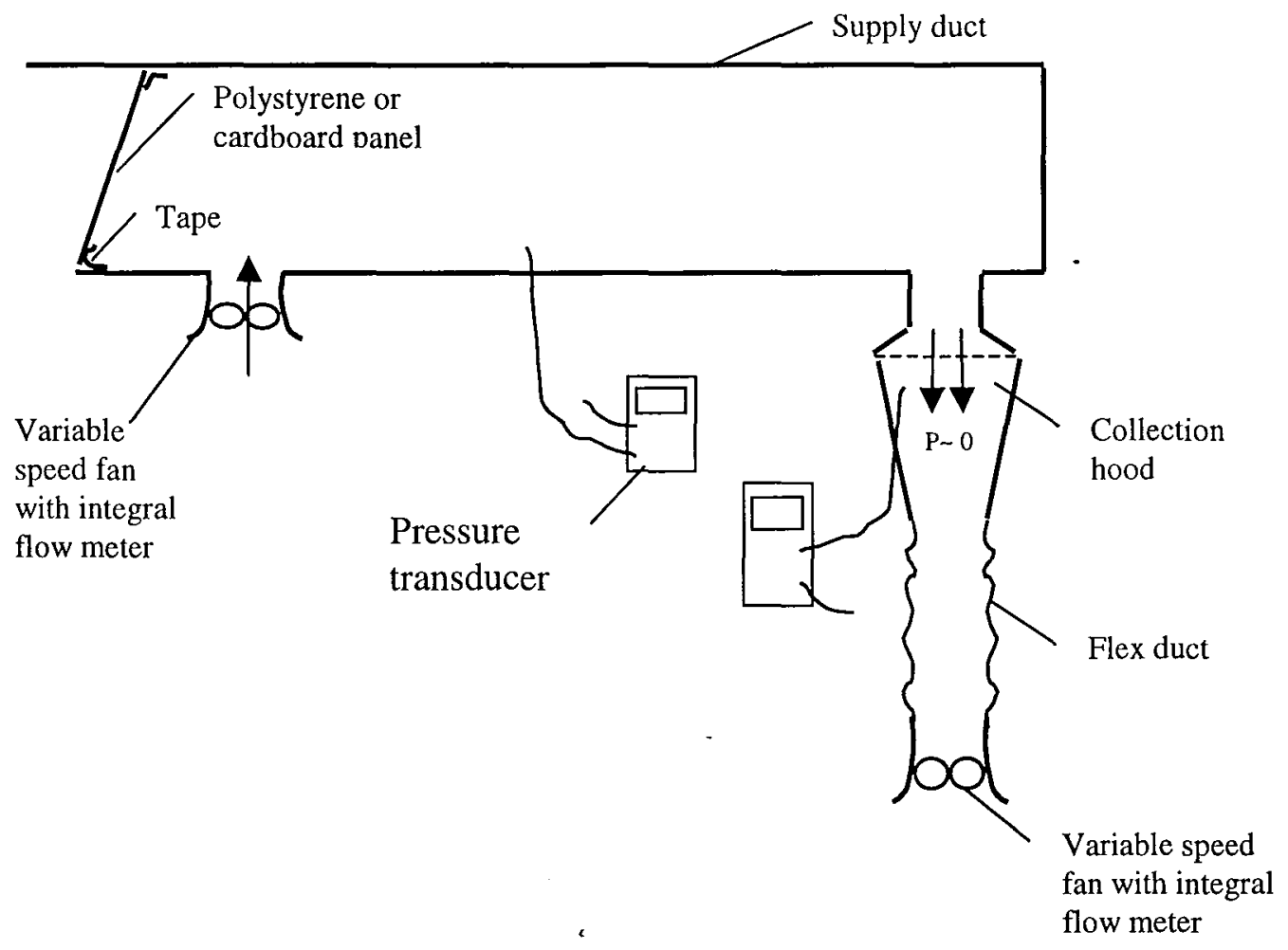

Figure 3. Illustration of apparatus used to measure rate of air leakage from duct system variable using a fan with integral flow meter to inject air into the duct and a fan-powered flow hood to measure the rate of air flow out of supply registers. 


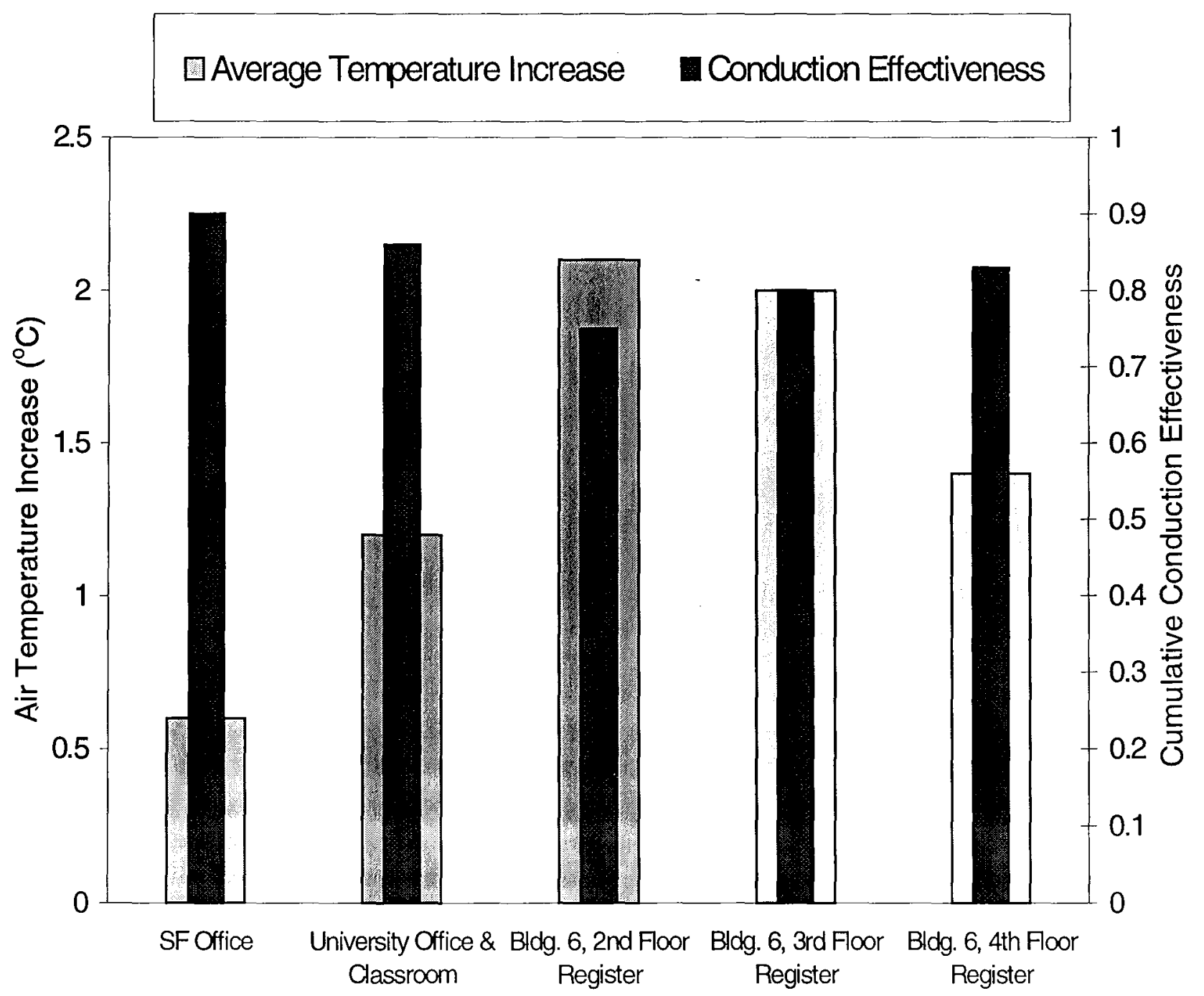

Figure 4. Air temperature decreases between cooling coils and supply registers and associated cumulative conduction effectiveness. 


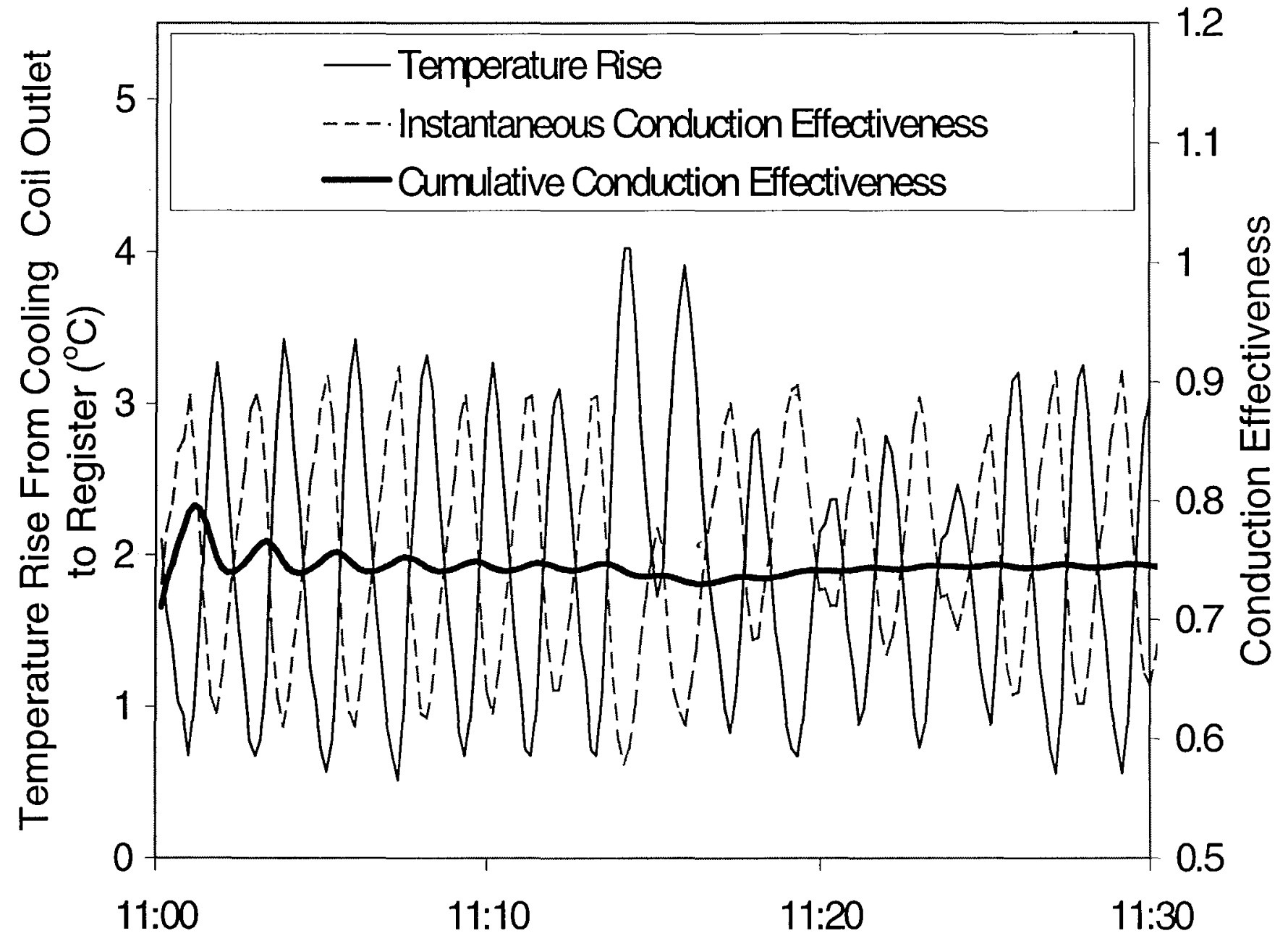

Figure 5. Temperature rise and conduction effectiveness versus time for the 2nd floor supply register of Building 6. 